\title{
Occurrence of Selliguea rynchophylla (Hook.) Fraser-Jenk. [Polypodiaceae] in Darjiling Himalaya: an addition to the flora of West Bengal, India
}

\author{
Alisha Thapa ${ }^{1}$, Norbu Sherpa ${ }^{2}$ and Nayan Thapa ${ }^{3}$ \\ ${ }^{1}$ Department of Botany, University of Kolkata, 35 Ballyguanj Circular Road, Kolkata 700019, \\ West Bengal, India \\ ${ }^{2}$ Botanical Survey of India, Baluakhani Road, Gangtok, 737103, Sikkim, India. \\ ${ }^{3}$ Communicating author: Directorate of Cinchona and other Medicinal plant, Mungpoo, 734313, \\ West Bengal, India; E-mail: nthapadcomp@gmail.com
}

[Received 21.04.2020; Revised 20.05.2020; Accepted 04.06.2020; Published 30.06.2020]

\begin{abstract}
Recent collection of Selliguea rynchophylla (Hook.) Fraser-Jenk. (Polypodiaceae) from the temperate habitat of Bhotey Khola area of the Kalimpong district (part of Darjiling Himalaya) is a new record of its occurrence for the state of West Bengal in India. The plant is sparsely distributed and its distribution in Indian subcontinent is known only from North-eastern India.
\end{abstract}

Key words: Selliguea rynchophylla, New record, Kalimpong, Darjeeling Himalaya, West Bengal

\section{INTRODUCTION}

Floristically rich Darjiling hills part of the Eastern Himalaya is home to diverse form of plants harbouring Sino-Himalayan elements in higher altitude (Das1995; Fraser Jenkins et al. 2015; Das \& Lungphi 2019). The Pteridophytes are the second most diverse group of land plants after the angiosperms with generally recognized 45 families (Christenhusz et al. 2011). The Darjiling hills is the northernmost district of the Indian state of West Bengal that lies between

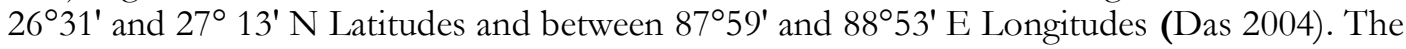
Hills of Darjiling form the outer fringes of the Singalila Range of Eastern Himalaya, covers an area of $2436.55 \mathrm{~km}^{2}$ with altitudinal variation ranging from $\pm 150 \mathrm{~m}$ (at Sukna) to $3660 \mathrm{~m}$ (at Sandakphu - Phalut), presents diverse topographical conditions and offer suitable habitat for the occurrence of wide range of plants (Das 1995). Though the district is floristically well explored but the occurrence of micro-niche in difficult terrains with negligible accessibility and alienated studies on the Kingdom Plantae has led some plants of the region remained undiscovered even today.

Regular field-trips were made in different vegetation tracts of Darjiling hills since April 2017 to May 2019 for floristic and phytosociological observations. The collected specimens were processed into mounted herbarium sheets following conventional techniques (Jain \& Rao 1977) and were identified by matching with pre-identified specimen in the herbarium of Llyod's Botanical Garden, as well as through consultation of published literature including (Mehra \& Bir 1964; Hara1971; Mathew 1971; Fraser-Jenkins 2008; Fraser-Jenkins et al. 2015). In April 2018, a fern was collected from the Bhotey Khola (Kalimpong district) area that was later on identified as Selliguea rynchophylla (Hook.) Fraser-Jenk. While studying the distribution of the species, it was revealed that the plant is known to grow in North-eastern India (Fraser Jenkins 2008) but was not recorded yet from the Darjiling hills as well as from the state of West Bengal. A brief description of the species along with sketches is provided here for its easy identification. 


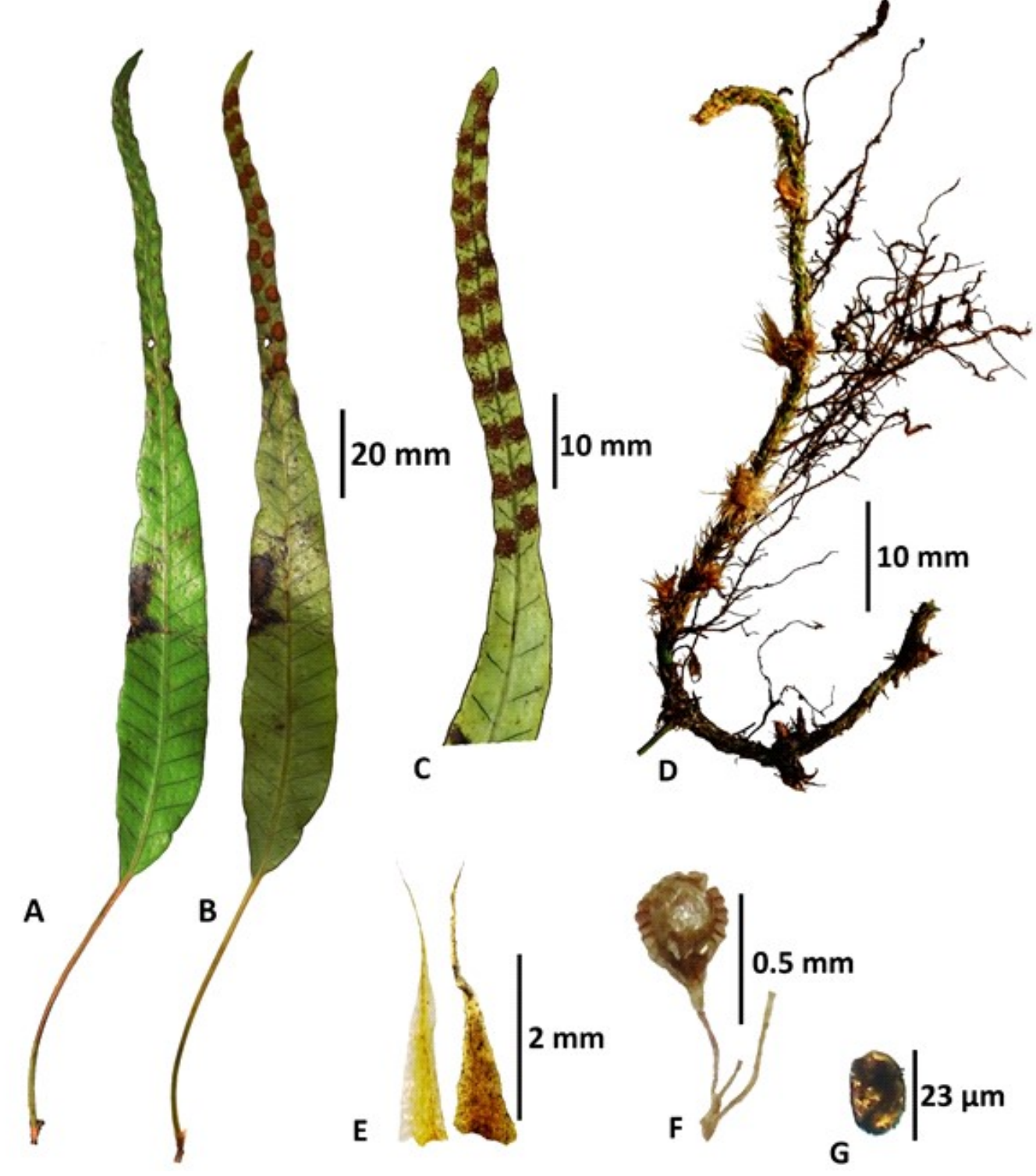

Plate I: Selliguea rynchophylla (Hook.) Fraser-Jenk.: A. Sterile frond; B. Fertile frond; C. Portion of fertile lamina; D. Rhizome - densely scaly; E. Scales; F. Sporangium (basic magnification $100 \mathrm{X})$; G. Spore (basic magnification $400 \mathrm{X}$ ).

Population of c.1000 individuals at one site were recorded on branches of Lithocarpuspachyphyllus (Kurz) Rehder and this species being in pristine, protected envuiorment is least threatened.

Selliguea rhynchophylla (Hook.) Fraser-Jenk., Taxon. Revis. Three Hundred Indian Subcont. Pterid. 48. 2008.

Polypodium rbynchophyllum Hook., Icon. Pl. 10: t. 954. 1854.

Pleopeltis rbynchophylla (Hook.) T. Moore, Index Fil. 78. 1857.

Phymatopsis rhynchophylla (Hook.) J.Sm., Hist. Fil. 104. 1875.

Phymatodes rhynchophylla (Hook.) Ching, Contrib. Inst. Bot. Natl. Acad. Peiping 2(3): 69-71. 1933. 
Crypsinus rbynchophyllus (Hook.) Copel., Gen. Fil. 206. 1947.

Phymatopteris rbynchophylla (Hook.) Pic.Serm., Webbia 28(2): 464. 1973.

Selliguea rbynchophylla (Hook.) H.Ohashi \& K.Ohashi, J. Jap. Bot. 84(5): 307-308. 2009, isonym.

Phymatodes okamotoi Tagawa, Act. Phytotax. Geobot. 7(3): 189. 1938.

Crypsinus okamotoi (Tagawa) Tagawa, Act. Phytotax. Geobot. 14(6): 194. 1952.

Selliguea okamotoi (Tagawa) Ralf Knapp, Ferns Fern Allies Taiwan 480. 2011.

Plants epiphytic to litophytic, erect, $8-12 \times 1-2 \mathrm{~cm}$; rhizome creeping, $0.4-0.8 \mathrm{~cm}$ in diameter, scaly; scales subulate with broad base, toothed, long-acuminate, $0.2-0.8 \mathrm{~cm}$, ferruginous. Fronds dimorphic, distant; sterile fronds simple; stipe $2-4 \mathrm{~cm}$; lamina simple, lanceolate, $6-10 \times 1-2 \mathrm{~cm}$, entire with irregular shallow notches, obtuse, base cordate, glabrous; Fertile fronds simple; stipe $2-3 \mathrm{~cm}$; lamina simple, linear to lanceolate, $5-10 \mathrm{x} 1-$ $2 \mathrm{~cm}$, entire, obtuse, soriferous portion contracted; sori medial, orbicular, between the rows of lateral veins, brown; sporangium ovoid, dark brown, $300-210 \mu \mathrm{m}$; Spores reniform, minutely spinous, pale brown, $23 \times 15 \mu \mathrm{m}$.

Exsiccatae: West Bengal, Darjiling hills, Kalimpong, Bhotay-khola Camp, N 27p 03'06.51" and E

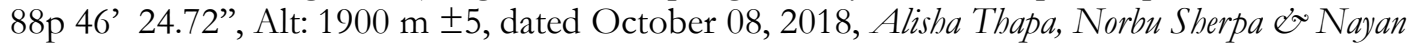
Thapa, LB014418 (LBH),

Global distribution: Nepal, Bhutan, India (Meghalaya, Sikkim), China, Myanmar, Philippines, Thailand, Laos, Vietnam

Local distribution: Bhotay Khola Camp area of Kalimpong district, West Bengal.

\section{LITERATURE CITED}

Christenhusz, M.J.; Zhang, X.C. \& Schneider, H. 2011. A linear sequence of extant families and genera of lycophytes and ferns. Phytotaxa 19: 7 - 54.

Das, A.P. 1995. Diversity of the Angiospermic flora of Darjeeling Hills. In A.K. Pandey (ed.), Taxonomy and Biodiversity. CBS, New Delhi. Pp. $118-127$.

Das, A.P. 2004. Floristic studies in Darjiling hills. Bull. Bot. Surv. India 43(1-4): 1 - 18.

Das, A. P. \& Lungphi, P. 2019. Floristic Studies vis-à-vis Medicinal Plants in the Eastern Himalaya - past and the present status. In: S.K. Tripathi, K. Upadhyaya \& N. Hegde (eds.), Medicinal Plants of India: Conservation and sustainable use. Today \& Tomorrow's Printers and Publishers, New Delhi. Pp. 39 - 56. ISBN: 978817096525.

Fraser-Jenkins, C.R. 2008. Taxonomic revision of Three hundred Indian Subcontinental Pteridophytes with a revised census list. Bishen Singh and Mahendra Pal Singh, Dehradun.

Fraser-Jenkins, C.R.; Kandel, D.R. \& Pariyar, S. 2015. Ferns and fern-allies of Nepal. National Herbarium and Plant Laboratories, Dept. of Plant Resources, Ministry of Forests and Soil Conservation, Govt. of Nepal, Kathmandu, Nepal.

Hara, H. 1971. Pteridophyta in The Flora of Eastern Himalayas, $2^{\text {nd }}$ report, University of Tokyo, Japan. Pp. $453-500$.

Jain, S.K. \& Rao, R.R. 1977 (reprint 2016). Field and Herbarium methods. Today and Tomorrow's Printers and publisher, New Delhi.

Matthew, K.M. 1971. Pteridophytes from the Darjeeling District. Bull. Bot. Soc. Bengal 25(1-2): $97-102$.

Mehra, P.N. \& Bir, S.S. 1964. Pteridophytic Flora of Darjeeling and Sikkim Himalayas. Bishen Singh and Mahendra Pal Singh, Dehradun. 